\title{
Fertilizers and biological products used for cultivation of perennial grasses on gray forest soils of the Middle Volga region
}

\author{
Faik N. Safiollin ${ }^{1 *}$, Salavat R. Suleymanov ${ }^{1}$, Svetlana V. Sochneva ${ }^{1}$, Nikolai V. Trofimov ${ }^{1}$, and Irina G. Malganova ${ }^{2}$ \\ ${ }^{1}$ Kazan State Agrarian University, 420015 Kazan, Russia \\ ${ }^{2}$ Kazan (Volga) Federal University, 420008 Kazan, Russia
}

\begin{abstract}
In recent years, fertilizers and biological products are widely used for cultivating perennial grasses to form highly productive agrocenoses and reduce the cost of feed. The issues of the use of biologically active substances for pre-sowing seeds of perennial herbs in combination with leaf fertilizing are of great practical importance. In the soil and climatic conditions of the Middle Volga region, the presowing seed treatment with Azotovite $2 \mathrm{~kg} / \mathrm{t}$ in combination with leaf treatment with Flavobacterine 4 1/ha depending provided an additional yield of 2.5-4.8 t/ha of green mass with a content of 440-960 feed units. The effect of the above biological products is equivalent to the application of $70-88 \mathrm{~kg} / \mathrm{ha}$ of mineral fertilizers and cost savings in the amount of 1.5-1.9 thousand rubles/ha.
\end{abstract}

\section{Introduction}

Assessing the current state of the agro-industrial complex of the developed countries, including the Russian Federation, setting the task of making it more innovative, we can sau that farmers have learned to use all accessible resources of land and nature. Therefore, much attention is paid to the use of scientific and technological achievements, including fertilizerstimulating compounds, biological preparations, and chelated micronutrient fertilizers. According to foreign [1-3] and Russian [4-6] scientists, they improve the stress resistance of plants, accelerate the accumulation of biomass, improve quality of the products, and contribute to a better wintering of winter rye and winter wheat due to internal reserves of cultivated crops. However, the use of biologically active substances is understudied, especially taking into account soil and climatic conditions of the forest-steppe zone of the Middle Volga region, which became the basis for the selection of the object and the direction of our research.

\section{The purpose and objectives of research}

The aim of the work is theoretical justification and development of practical methods for pre-sowing seed treatment of perennial grasses with biologically active substances in combination with leaf treatment with Flavobacterine.

To achieve this goal, the following tasks were set:

- to conduct a comparative assessment of the influence of the calculated norms of mineral fertilizers and biological products on the productivity of single and multivariate crops of multi-crop ryegrass;
- to study the nutritional value of ryegrass feed depending on the plant nutrition;

- to calculate the value of the possible substitution of mineral fertilizers with biological products and cost savings in the production of energy-rich ryegrass feed.

\section{Research program and methodology}

The main research method was a two-factor field experiment. Factor A (types of grass stands): singlesowing crops of ryegrass multi-crop Leningrad 809 (control); ryegrass $(60 \%)+$ boneless boneless rump Morshan $710(40 \%)$; ryegrass $(60 \%)+$ meadow fescue Kazan $(40 \%)$. Factor B (fertilizers and biologics): control (without fertilizers); N88P35K43 (per $30 \mathrm{t} / \mathrm{ha}$ of green mass); Azotovite $2 \mathrm{~kg} / \mathrm{t}$ of seeds + Flavobacterine $4 \mathrm{l} / \mathrm{ha}$; Albite $40 \mathrm{~g} / \mathrm{t}$ seeds + Flavobacterine 4 1/ha; Rizogrine $3 \mathrm{~kg} / \mathrm{t}$ of seeds + Flavobacterine 4 1/ha.

The studies were conducted in 2015-2018 on the experimental field of the Faculty of Agronomy (GPS coordinates: N $55^{\circ} 39^{\prime} 51^{\prime \prime}$, E $\left.49^{\circ} 1^{\prime} 1^{\prime} 33^{\prime \prime}\right)$ of Kazan State Agrarian University. The content of humus was $3.91 \%$, mobile phosphorus - 152 and exchange potassium $168 \mathrm{mg} / \mathrm{kg}$ of soil according to the Kirsanov's criterion. Acidity: the soil is slightly acidic ( $\mathrm{pH}$ of salt extract 5.9). The density was within the normal range $-1.2 \mathrm{~g} / \mathrm{cm}^{3}$, the lowest moisture capacity was quite high (the soil can retain up to $29 \%$ moisture).

The experiment was carried out in four replicates, the total area of the plot was $36 \mathrm{~m}^{2}$, the accounting area was $21 \mathrm{~m}^{2}$. Accounting, observation, analysis and processing of research results were carried out according to the methodology of the All-Russian Research Institute of Feed named after V.R. Williams [7, 8].

We studied the effect of those drugs that are

Corresponding author: faik1948@mail.ru 
approved for the use in the Russian Federation. In order to comply with the principle of the only difference in single- and multivariate crops of multi-cut ryegrass, root treatment with mineral fertilizers for the planned green mass yield of $30 \mathrm{t} / \mathrm{ha}$ and foliar top treatment were carried out in two doses (each dose - 50\%) - at the beginning of perennial regrowth grasses (early May) and after the first mowing (the first decade of June).

The main and pre-sowing preparations of the soil were generally accepted for the forest-steppe zone of the Middle Volga region.

The agrometeorological conditions did not differ from the long-term average indicators. The amount of precipitation for May - September ranged from 134 (2018) to $286 \mathrm{~mm}$ (2017). By thermal resources, in May 2015 and 2016, average daily air temperatures of +16.3 and $15.3{ }^{\circ} \mathrm{C}$ against normal $+13.0^{\circ} \mathrm{C}$ were recorded.

\section{Results}

To achieve cattle productivity of 5 thousand liters of milk per year and daily weight gain of $800-1000 \mathrm{~g}$, it is necessary to harvest 5 thousand feed units. This task is not simple, since the reserves for increasing the cultivated area of fodder crops have been exhausted. In this regard, an increase in feed production should not be achieved by means that are economically feasible and justify the work of modern farmers. From this point of view, the results of studies on the influence of biological products on the productivity of perennial herbs are of special attention (Table 1).

In the soil and climatic conditions of the foreststeppe zone of the Middle Volga region, the ryegrass multi-mowing formed $18.6 \mathrm{t} / \mathrm{ha}$ of green mass without the use of mineral fertilizers and biological products for 4 years.

The annual feeding with N88P35K43 increased the yield of multi-crop ryegrass to $27.1 \mathrm{t} /$ ha of green mass.

Biological products Azotovite at the rate of $2 \mathrm{~kg} / \mathrm{t}$ of seeds + Flavobacterin in two doses $(2 \mathrm{l} / \mathrm{ha}$ in spring and after the first mowing) provided an increase in the green mass yield of $4.2 \mathrm{t} / \mathrm{ha}$, which is 28 percent higher than in the control variant.

When sowing ryegrass mixed with bezelless rump and applying N88P35K43, the actual yield was as close as possible to the planned one $-99.3 \%$ versus $95 \%$ when sowing this crop mixed with meadow fescue.

The comparative evaluation of the effectiveness of biological products and NPK by the yield of green mass would not be complete, since the amount of moisture in the green mass can be different. Therefore, in our studies, the dry matter content was determined by the thermostat-weighting method with a further calculation of the gross collection of dry weight from 1 ha of crops of perennial grasses.

Despite a significant decrease in dry matter under the influence of the calculated norms of mineral fertilizers, the highest gross yield of dry matter was obtained in the following experimental options:

- gross collection of dry weight from single-species crops of multi-crop ryegrass amounted to $6.8 \mathrm{t} / \mathrm{ha}$;
- ryegrass-bonfire grass provided 7.9 t/ha of dry weight;

- ryegrass-oatmeal crops for gross collection of dry weight were inferior to ryegrass-bonfire crops only by $0.4 \mathrm{t} / \mathrm{ha}$, but surpassed single-species crops by $0.7 \mathrm{t} / \mathrm{ha}$.

Table 1. Comparative assessment of the effect of mineral fertilizers and biological products on the productivity of perennial herbs (2015-2018)

\begin{tabular}{|c|c|c|c|c|}
\hline 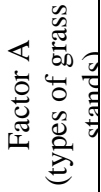 & $\begin{array}{c}\text { Factor B (fertilizers and } \\
\text { biological products) }\end{array}$ & 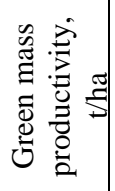 & 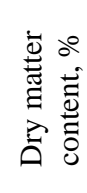 & 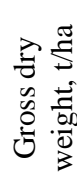 \\
\hline \multirow{5}{*}{ 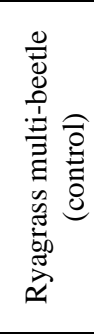 } & Control (without fertilizer) & 18.6 & 27.2 & 5.1 \\
\hline & $\begin{array}{c}\mathrm{N}_{88} \mathrm{P}_{35} \mathrm{~K}_{43}(30 \mathrm{t} / \mathrm{ha} \text { green } \\
\text { masses })\end{array}$ & 27.1 & 25.1 & 6.8 \\
\hline & $\begin{array}{c}\text { Azotovit } 2 \mathrm{~kg} / \mathrm{t} \text { seeds }+ \\
\text { Flavobacterin } 4 \text { 1/ha }\end{array}$ & 23.8 & 26.2 & 6.2 \\
\hline & $\begin{array}{l}\text { Albit } 40 \mathrm{~g} / \mathrm{t} \text { seeds }+ \\
\text { Flavobacterin } 41 / \mathrm{ha}\end{array}$ & 21.9 & 26.8 & 5.9 \\
\hline & $\begin{array}{c}\text { Rizogrin } 3 \mathrm{~kg} / \mathrm{t} \text { seeds }+ \\
\text { Flavobacterin } 4 \text { 1/ha }\end{array}$ & 22.1 & 26.0 & 5.7 \\
\hline \multirow{5}{*}{ 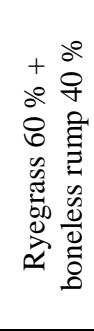 } & Control (without fertilizer) & 20.9 & 28.3 & 5.9 \\
\hline & $\begin{array}{c}\mathrm{N}_{88} \mathrm{P}_{35} \mathrm{~K}_{43}(30 \mathrm{t} / \mathrm{ha} \text { green } \\
\text { masses })\end{array}$ & 29.8 & 26.4 & 7.9 \\
\hline & $\begin{array}{c}\text { Azotovit } 2 \mathrm{~kg} / \mathrm{t} \text { seeds }+ \\
\text { Flavobacterin } 4 \text { 1/ha }\end{array}$ & 25.6 & 27.0 & 6.9 \\
\hline & $\begin{array}{l}\text { Albit } 40 \mathrm{~g} / \mathrm{t} \text { seeds }+ \\
\text { Flavobacterin } 4 \text { 1/ha }\end{array}$ & 23.4 & 27.9 & 6.5 \\
\hline & $\begin{array}{c}\text { Rizogrin } 3 \mathrm{~kg} / \mathrm{t} \text { seeds }+ \\
\text { Flavobacterin } 4 \text { 1/ha }\end{array}$ & 23.9 & 27.2 & 6.5 \\
\hline \multirow{5}{*}{ 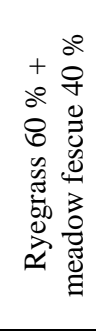 } & Control (without fertilizer) & 20.0 & 27.9 & 5.6 \\
\hline & $\begin{array}{c}\mathrm{N}_{88} \mathrm{P}_{35} \mathrm{~K}_{43}(30 \mathrm{t} / \mathrm{ha} \text { green } \\
\text { masses })\end{array}$ & 28.6 & 26.1 & 7.5 \\
\hline & $\begin{array}{c}\text { Azotovit } 2 \mathrm{~kg} / \mathrm{t} \text { seeds }+ \\
\text { Flavobacterin } 4 \text { 1/ha }\end{array}$ & 24.8 & 26.9 & 6.8 \\
\hline & $\begin{array}{l}\text { Albit } 40 \mathrm{~g} / \mathrm{t} \text { seeds }+ \\
\text { Flavobacterin } 4 \text { l/ha }\end{array}$ & 23.0 & 27.1 & 6.2 \\
\hline & $\begin{array}{c}\text { Rizogrin } 3 \mathrm{~kg} / \mathrm{t} \text { seeds }+ \\
\text { Flavobacterin } 4 \text { 1/ha }\end{array}$ & 23.2 & 26.8 & 6.2 \\
\hline$\stackrel{\tilde{\theta}}{\tilde{\theta}}$ & $\begin{array}{c}\mathrm{A} \\
\mathrm{B} \\
\mathrm{AB}\end{array}$ & $\begin{array}{l}0.32 \\
0.40 \\
0.45\end{array}$ & & \\
\hline
\end{tabular}

As a result, due to sowing ryegrass, meadow fescue and beechless rump, the same mineral nutrition provides additional $0.7-1.1 \mathrm{t} / \mathrm{ha}$.

The studied biological products had a positive effect on the yield of green and dry mass of perennial grasses. The pre-sowing seed treatment with Azotovit at the rate of $2 \mathrm{~kg} / \mathrm{t}$ in combination with two-fold foliar application of Flavobacterine ( 2 1/ha) at the beginning of the growth of perennial grasses and after the first mowing is efficient:

- an increase in the dry weight of single-species ryegrass crops was 22 percent;

- an increase in dry mass of ryegrass-bonfire was 17 percent;

- ryegrass-oatmeal crops occupied an intermediate position between them with an increase of 21 per cent.

Albite in the amount of $40 \mathrm{~g} / \mathrm{t}$ and Rizogrine in the 
amount of $3 \mathrm{~kg} / \mathrm{t}$ in combination with Flavobacterine also provided significant increases in the range of 10-12 percent.

Therefore, in order to obtain 6.2-6.9 t/ha of dry mass, it is necessary to treat seeds with Azotovite $(2 \mathrm{~kg} / \mathrm{t})$; during the growing season, it is necessary to apply (in early spring and after the first mowing) Flavobacterine at the rate of $21 /$ ha $+3001 /$ ha $\mathrm{H} 2 \mathrm{O}$.

A steady trend to increase the content of the main nutrient - crude protein in the dry mass of multigraded ryegrass was observed: in the mixture with beefless rump, an increase was 12.8 , and with meadow oatgrass $-14.6 \%$ versus $12.4 \%$ in single species crops. In this regard, the mixed crops of the multi-rowed ryegrass provided the highest yields of crude protein: $1163 \mathrm{~kg} / \mathrm{ha}$ mixed with meadow fescue against the estimated NPK of $30 \mathrm{t} / \mathrm{ha}$ of green mass and $1153 \mathrm{~kg} / \mathrm{ha}$ in the mixture with bezostost rump, which is 14 and $13 \%$ higher compared to single-species crops.

The high efficiency of biological products should be emphasized. Azotovite + Flavobacterine ensured an increase by $843 \mathrm{~kg} / \mathrm{ha}$, ryegrass-krestsevye - by 918 and ryegrass-oatmeal - by $966 \mathrm{~kg} / \mathrm{ha}$.

When assessing the nutritional value of perennial grasses, the content and gross collections of crude oil cannot be excluded from the analysis. For example, it was found that dairy cows require $60 \%$ of raw fat, excreted in milk $[9,10]$. With a productivity of $151 /$ day of milk with a oil content of $4 \%$, the cow should receive $360 \mathrm{~g}$ of raw oil per day. Currently, in order to balance the cattle diet for this energy material, many farms are forced to purchase oilseed. Meanwhile, there is another possibility of increasing its content and production by selecting perennial grasses genetically rich in raw oil and regulating their nutritional background (Fig. 1).

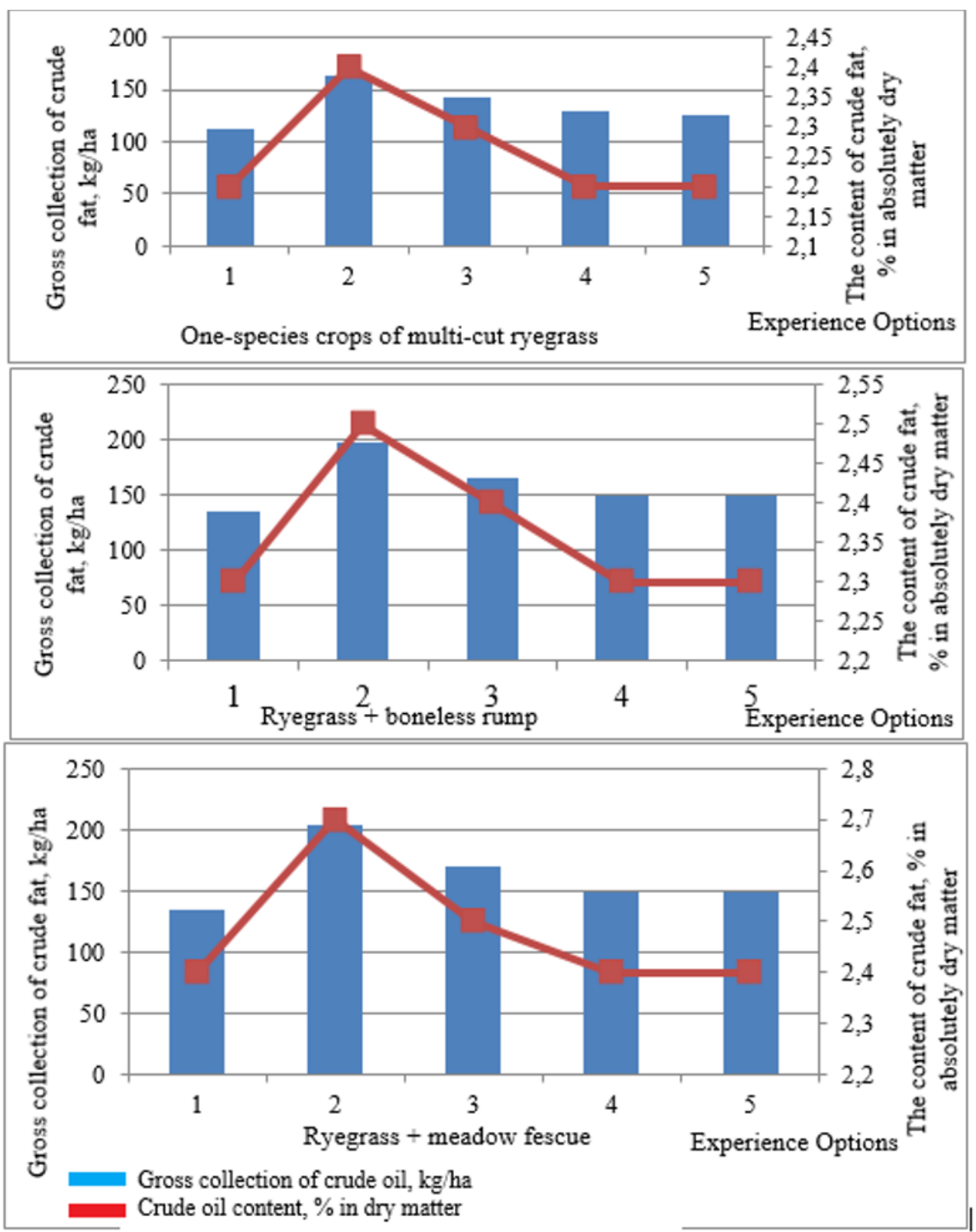

Fig. 1. Content and gross collections of crude oil depending on the nutritional options of ryegrass agrocenoses (2015-2018) 
All biological products used in the technology of cultivation of ryegrass agrocenoses were effective:

- for single-species crops of ryegrass, this technology provided an increase by $31 \mathrm{~kg} / \mathrm{ha}$ of crude fat;

- for mixed sowing of ryegrass with rumpless rump, an increase was was $166 \mathrm{~kg} / \mathrm{ha}$;

- multi-variety crops with meadow fescue provided an increase by $36 \mathrm{~kg} / \mathrm{ha}$.

Mathematical calculations show that with such a content of raw oil and its gross collection from 1 ha of crops, $14 \mathrm{~kg}$ of dry mass of ryegrass feed cover the daily need of dairy cows for energy material.

The combination of pre-sowing treatment of seeds with Azotovite and Flavobacterine provided additional 802 fodder units from single-species crops of multi-crop ryegrass, 876 fodder units from ryegrass-bonfire meadows and 960 fodder units from ryegrass-fescue grasses, which is equivalent to $800-9601$ milk per hectare of perennial grasses with the content of multigrained ryegrass ( 1 feed. unit $=11 \mathrm{milk}$ ).

The use of modern biological products as alternative food sources increases the saturation of feed with exchange energy from 12.1 to $14.9 \mathrm{MJ} / \mathrm{kg}$ against normative 9-10 MJ.

As a result, the return on energy costs increases for single-species ryegrass crops from 2.2 (without fertilizers) to 3.2 in the variant with NPK and up to $2.6-$ in the variant with Azotovite + Flavobacterine. For ryegrass-bonfire meadows, the analyzed indicators were $2.6 ; 3.8 ; 3.3$ and for ryegrass-oatmeal crops - 3.1; 4.0; $3.6[11]$.

The most important question is whether it is possible to save on mineral fertilizers by using biological products for the pre-sowing treatment of seeds and during the growing season of plants.

The value of the possible NPK substitutions was calculated using the following proportion:

$$
\begin{gathered}
\mathrm{PrNPK}-100 \% \\
\mathrm{Pp}_{\mathrm{b}}-\mathrm{X} \%
\end{gathered}
$$

where $\mathrm{X}$ is the desired NPK substitution value, \%;

$\mathrm{Pr}_{\mathrm{NPK}}$ - an increase in feed units in the variant with mineral fertilizers for the planned yield of $30 \mathrm{t} / \mathrm{ha}$ of green mass;

$\operatorname{Pr}_{b}$ - an increase in feed units as a result of the application of biological products (Table 2).

According to our calculations, pre-sowing seed treatment with Azotovite at the rate of $2 \mathrm{~kg} / \mathrm{t}$ and treatment with Flavobacterine at the rate of 2 1/ha in spring and after the first mowing replaces 53 percent of nitrogen-phosphorus and potassium fertilizers versus 48 and $51 \%$ in case of ryegrass-bonfire and ryegrassoatmeal crops.

The value of the possible NPK substitution with biological products Albite + Flavobacterine and Rizogrine + Flavobacterine is half less and ranges from 20 to $34 \%$, depending on the botanical composition of grass.

Knowing the percentage of NPK substitution, we can find the substitution value in $\mathrm{kg} / \mathrm{ha}$ :

$$
\begin{aligned}
& \mathrm{NPK}_{\mathrm{r}}-100 \% \\
& \mathrm{NPK}_{\mathrm{b}}-\mathrm{X} \%
\end{aligned}
$$

where $\mathrm{X}$ is the desired value, $\mathrm{kg} / \mathrm{ha}$;

$\mathrm{NPK}_{\mathrm{r}}$ - the estimated rate of mineral fertilizers for the planned yield of $30 \mathrm{t} / \mathrm{ha}$ of green mass $(166 \mathrm{~kg} / \mathrm{ha}$ a.a.);

$\mathrm{NPK}_{b}$ is the amount of NPK substitution with biological products, $\%$.

\begin{tabular}{|c|c|c|c|c|c|c|}
\hline \multirow{2}{*}{ 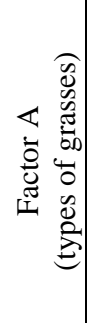 } & \multirow{2}{*}{$\begin{array}{l}\text { Factor B (fertilizers } \\
\text { and biological } \\
\text { products) }\end{array}$} & \multicolumn{2}{|c|}{$\begin{array}{c}\text { NPK } \\
\text { substitutio } \\
\text { n value }\end{array}$} & \multirow{2}{*}{ 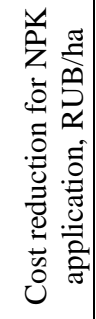 } & \multirow{2}{*}{ 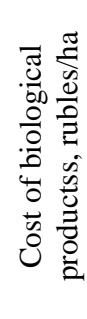 } & \multirow{2}{*}{ 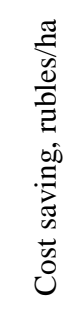 } \\
\hline & & $0^{\circ}$ & 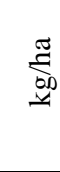 & & & \\
\hline \multirow{5}{*}{ 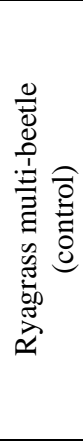 } & $\begin{array}{l}\text { Control (without } \\
\text { fertilizers) }\end{array}$ & - & - & - & - & - \\
\hline & $\begin{array}{c}\mathrm{N}_{88} \mathrm{P}_{35} \mathrm{~K}_{43}(30 \mathrm{t} / \mathrm{ha} \\
\text { green masses) }\end{array}$ & - & - & - & - & - \\
\hline & $\begin{array}{c}\text { Azotovite } 2 \mathrm{~kg} / \mathrm{t} \text { seeds } \\
+ \text { Flavobacterine } 4 \\
\text { 1/ha }\end{array}$ & 53 & 88 & 3520 & 1643 & 1877 \\
\hline & \begin{tabular}{|l|} 
Albite $40 \mathrm{~g} / \mathrm{t}$ seeds + \\
Flavobacterine $4 \mathrm{l} / \mathrm{ha}$ \\
\end{tabular} & 34 & 56 & 2240 & 1302 & 938 \\
\hline & $\begin{array}{c}\text { Rizogrine } 3 \mathrm{~kg} / \mathrm{t} \text { seeds } \\
+ \text { Flavobacterine } 4 \\
1 / \mathrm{ha}\end{array}$ & 30 & 50 & 2000 & 1445 & 555 \\
\hline \multirow{5}{*}{ 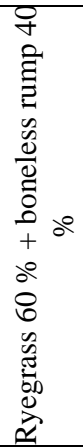 } & $\begin{array}{c}\text { Control (without } \\
\text { fertilizers) }\end{array}$ & - & - & - & - & - \\
\hline & $\begin{array}{c}\mathrm{N}_{88} \mathrm{P}_{35} \mathrm{~K}_{43}(30 \mathrm{t} / \mathrm{ha} \\
\text { green masses) }\end{array}$ & - & - & - & - & - \\
\hline & \begin{tabular}{|c}
$\begin{array}{c}\text { Azotovite } 2 \mathrm{~kg} / \mathrm{t} \text { seeds } \\
+ \text { Flavobacterine } 4 \\
1 / \mathrm{ha}\end{array}$ \\
\end{tabular} & 48 & 80 & 3200 & 1643 & 1557 \\
\hline & \begin{tabular}{|l|} 
Albite $40 \mathrm{~g} / \mathrm{t}$ seeds + \\
Flavobacterine 4 1/ha \\
\end{tabular} & 20 & 33 & 1320 & 1302 & 18 \\
\hline & $\begin{array}{c}\text { Rizogrine } 3 \mathrm{~kg} / \mathrm{t} \text { seeds } \\
\text { + Flavobacterine } 4 \\
\text { 1/ha } \\
\end{array}$ & 23 & 38 & 1520 & 1445 & 75 \\
\hline \multirow{5}{*}{ 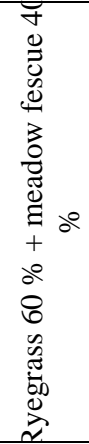 } & $\begin{array}{l}\text { Control (without } \\
\text { fertilizers) }\end{array}$ & - & - & - & - & - \\
\hline & $\begin{array}{c}\mathrm{N}_{88} \mathrm{P}_{35} \mathrm{~K}_{43}(30 \mathrm{t} / \mathrm{ha} \\
\text { green masses })\end{array}$ & - & - & - & - & - \\
\hline & $\begin{array}{c}\text { Azotovite } 2 \mathrm{~kg} / \mathrm{t} \text { seeds } \\
+ \text { Flavobacterine } 4 \\
\text { 1/ha }\end{array}$ & 51 & 85 & 3400 & 1643 & 1757 \\
\hline & \begin{tabular}{|l|} 
Albite $40 \mathrm{~g} / \mathrm{t}$ seeds + \\
Flavobacterine $4 \mathrm{l} / \mathrm{ha}$ \\
\end{tabular} & 20 & 33 & 1320 & 1302 & 18 \\
\hline & $\begin{array}{c}\text { Rizogrine } 3 \mathrm{~kg} / \mathrm{t} \text { seeds } \\
+ \text { Flavobacterine } 4 \\
1 / \mathrm{ha}\end{array}$ & 24 & 37 & 1480 & 1445 & 35 \\
\hline
\end{tabular}

Table 2. The value of the possible NPK substitution and economic efficiency of the use of biological products for cultivation of perennial grasses

The final calculations show that Azotovite $2 \mathrm{~kg} / \mathrm{t}+$ Flavobacterin 4 1/ha for single-species crops replace $88 \mathrm{~kg} / \mathrm{ha}$ of mineral fertilizers, $80 \mathrm{~kg} / \mathrm{ha}$ - for ryegrassbonfire grasses and $85 \mathrm{~kg} / \mathrm{ha}$ of NPK.

The cost of purchase, transportation, storage, application of mineral fertilizers minus compensation payments of the Ministry of Agriculture of the Russian Federation is 40 rubles $/ \mathrm{kg}$ a.v. Based on this, we determined a decrease in the cost when using mineral fertilizers. 
However, the factor of reducing the cost is not decisive, since for the final calculation it is necessary to take into account the cost of pre-sowing seed treatment and 2-fold foliar feeding of plants with Flavobacterine.

After all these calculations, the costs were subtracted from the amount of cost reduction due to the replacement of NPK with biological products. Singlespecies sowing of ryegrass, pre-sowing treatment of seeds with Azotovite in combination with Flavobacterine allows for saving 1876 rubles/ha, and poly-species sowing allows for saving 1557-1757 rubles/ha.

\section{Conclusion}

The widespread use of biological products is a promising direction for increasing production of high-quality and energy-saturated feeds:

1. Azotovite and Flavobacterine provide an additional yield of 2.5-4.8 t/ha of green mass (0.6-2.0 t/ha of dry matter) and 440-960 feed units.

2. Under the influence of Azotovite in combination with Flavobacterine, the saturation of $1 \mathrm{~kg}$ of dry mass of cereal perennial grasses with the participation of multi-mowing ryegrass of metabolic energy increases from 12.0 to $13.3 \mathrm{MJ}$ against the standard 9-10 MJ.

3 . The effectiveness of the above biological products is equivalent to the introduction of $80-88 \mathrm{~kg} / \mathrm{ha}$ of mineral fertilizers. Cost savings depending on the botanical composition of perennial grasses are 15571876 rubles/ha.

\section{References}

1. M. Halpern, U. Yermiyahu, A. Bar-Tal, M. Ofek, D. Minz, T. Muller, Advances in Agronomy 130, 141-174 (2015)

2. A.K. Srivastava, P. Suprasanna, R. Pasala, P.S. Minhas, Advances in Agronomy 137, 237-278 (2016)

3. J.R. Reeve, L.A. Hoagland, J.J. Villalba, P.M. Carr, A. Atucha, C. Cambardella, D.R. Davis, K. Delate, Advances in Agronomy 137, 319-367 (2016)

4. R.M. Nizamov, F.N. Safiollin, M.M. Khismatullin, M.I. Giliazov, F.A. Davletov, R.S. Shakirov, Int. J. of Advanced Biotechnology and Res. (IJABR) 10(1), 341-347 (2019)

5. R.I. Safin, L.Z. Karimova, F.N. Safiollin, Sh.Z. Validov, B.G. Ziganshin, K.Z. Karimov, G.S. Minnullin, E3S Web of Conf. 91, 185-193 (2019)

6. F.Sh. Shaikhutdinov, I.M. Serzhanov, Grain Farm 2(50), 12-17 (2017)

7. V.M. Kosolapov et al., Methods of feed analysis 219 (Ugreshskaya Printing House, Moscow, 2011)

8. The program and methodology for conducting scientific research on meadow cultivation (according to the Interdepartmental Coordination Program of Res. of the Russian Agricultural Academy for 2011-2015), ed. A.A. Kutuzova, K.N. Privalova 192 (FSEI RCSC, Moscow, 2011)

9. L.P. Zaripova, F.S. Gibadullina, Achievements of Sci. and Techn. 11, 36-37 (2008)

10. F.S. Gibadullina, L.P. Zaripova, Bull. of the Russian Academy of Agricultural Sci. 5, 59-60 (2011)

11. I.P. Talanov, L.Z. Karimova, Proc. of the Kuban State Agrarian Univ. 2(53), 122-125 (2015) 